\title{
THE DIVINITY COSMOLOGICAL MODEL OF IBN AL-'ARABI: THE RELATIONS BETWEEN MYSTICAL AND LOGIC
}

\author{
Taufiqurrahman \\ Universitas Islam Negeri (UIN) Imam Bonjol Padang, taufiqurrahman@uinib.ac.id
}

(92021 by the authors. Submitted for possible open access publication under the terms and conditions
of the Creative Commons Attribution-ShareAlike 4.0 International License (CC-BY-SA)
license (https://creativecommons.org/licenses/by-sa/4.0/)
do) DOI: http://dx.doi.org/10.30983/fuaduna.v5i1.4164

\begin{abstract}
This article analyzes the cosmological model of the divinity of Ibn al-'Arabi based on relations between mystical and logic. This research is a literature review with a descriptive analytics method. In this case, it reveals and describes as it is Ibn al-'Arabi's cosmological model of the divine, then analyzed and interpreted to obtain the proper data. This research finds that Ibn al-'Arabi's cosmological model of divine relevant to the times and is a thought that brings humans to the 'presence' of God. Ibn al-'Arabi's cosmological model of the divine is not only transcendental theological but also mysticism in character. This study is important since it reveals much deeper about the cosmological model of the divinity of Ibn al-'Arabi. Although research on Ibn al-'Arabi has been widely carried out including on Ibn al-'Arabi's divine cosmology, however, re-examining the model contained in Ibn al-'Arabi's divine cosmology has the potential to rediscover new reinterpretations, so that this research can be used as a foundation in the study of Islamic thought.
\end{abstract}

Keywords: Divine Cosmology; Ibn al-'Arabi, Mystical and Logic.

\begin{abstract}
Abstrak
Artikel ini menganalisis tentang model kosmologi ketubanan Ibn al-'Arabi yang berpijak pada jalinan antara mistis dan nalar. Penelitian ini adalah kajian kepustakaan, dengan metode deskriptif analitis. Dalam hal ini mengungkapkan dan menggambarkan secara apa adanya tentang model kosmologi ketuhanan Ibn al-'Arabi, selanjutnya dianalisis dan dilakukan interpretasi sehingga ditemukan data yang diinginkan. Penelitian ini menemukan bahwa model kosmologi ketuhanan Ibn al-'A rabi masib dan sangat relevan dengan zaman serta merupakan pemikiran yang membawa manusia akan 'kehadiran' Tuban. Sebab model kosmologi ketuhanan Ibn al-'Arabi tidak hanya bersifat teologis transendental semata, melainkan juga bercorak tasawuf. Penelitian ini penting karena menguak tentang model kosmologi ketuhanan Ibn al-'Arabi secara mendalam. Walaupun penelitian tentang Ibn al-'Arabi telab banyak dilakukan termasuk tentang kosmologi ketuhanan Ibn al-'Arabi, namun meneliti kembali model yang terkandung dalam kosmologi ketuhanan Ibn al-'Arabi berpotensi menemukan kembali reinterpretasi baru, sehingga penelitian ini dapat dijadikan landasan dalam kajian pemikiran Islam.
\end{abstract}

Kata Kunci: Ibn al-'Arabi; Kosmologi Ketuhanan; Mistis dan Nalar. 


\section{INTRODUCTION}

Amongst a lot of mystical philosophy thought (Sufism Philosophy) in Islam, Ibn al'Arabi is one of the unique models due to his expertise in formulating his mystical experience into philosophy language; hence the presented philosophy is not solely rational, but accomplished with dranqiyyah (intuitive) thought motive. The other unique characteristics of Ibn al-'Arabi are his great ability in provoking debate among religious scholars. The most highlighted thought of Ibn al'Arabi is about wabdat al-wujud (the unity of being). ${ }^{1}$

Based on his concept of wabdat al-wujud, Ibn al-'Arabi had developed his divine thought throughout intellectual creation and his depth mystical understanding, which is very different from the thinking model developed by numbers of Muslim theologians (sunni) who tend to understand god more on dialectic process based on verses in Qur'an strengthened by rational arguments.

Theological divinity thought is sometimes apologetic according to each perspective of religious streams, and it emphasizes more on truth claim which is based on argumentation power and various hidden purposes lied behind certain group or faction names. In part, the theology thinking model is considered dry since it focuses more on god transcendence, hence those who rely on an sich rational model will not be aware of their inward functionality in understanding the inward itself.

This is what differentiates the rational theology thinking model and mystical philosophers, particularly those who tried to balance God as imman ence instead of transcendence. Through the immanence approach, God is not only the focus of the discussion, but God is implemented toward the human spirituality system. God is understood as the existence of human spirituality.

1 Oludamini Ogunnaike, "Inception and Ibn 'Arabi," Journal of Religion \& Film 17, no. 2 (2013): 1-50, http://digitalcommons.unomaha.edu/jrf/vol17/iss2/10; Michael Ebstein, "Classifications of Knowledge in Classical Islamic Mysticism: From Eastern Sufi Sources to the
There are several studies which are the author's preliminary studies in examining Ibn al'Arabi's thoughts, including first, research written in 2014 by Happy Susanto about Philosophy of Humans Ibn al-'Arabi, which focuses on researching the essence of human beings based on Ibn al'Arabi's vision, its characteristics and effects. Second, a study entitled Ibn al-'Arabi's Rejection of Religious Pluralism written by Kholid Karomi in 2014 examines Ibn al-'Arabi's rejection of religious pluralism in his thoughts on wabdat al-adyan. Third, research that is written by A.H. Haris Fakhrudin in 2012 about The Concept of Freedom in Sufism: Ibn al'Arabi's Perspective, which discusses the meaning of freedom according to Ibn al-'Arabi's thought discourse. Fourth, a study that was written by Abd. Halim Rofi'ie in 2010 entitled Wabdat al-Wujud based on Ibn al-'Arabi's Thought, focuses on examining thoughts about wahdat al-wujud Ibn al'Arabi.

Based on the preliminary study above, there has been a lot of research on Ibn al-'Arabi. However, re-examining the model contained in Ibn al-'Arabi's divine cosmology rediscovers a new reinterpretation, so that this research can be used as a basis in the study of Islamic thought.. These preliminary studies can be an additional reference for author research on Ibn al-'Arabi's thoughts and it can provide references for further research.

This research is a literature review with a descriptive analytics method, an attempt to reveals and describes as it is and analyze by sorting one concept among other concepts to obtain the proper data. In this case, attempts to describe Ibn al- 'Arabi's cosmological model of the divine, then analyzes what kind of Ibn al-'Arabi's cosmological model, to get one conclusion. These research sources are various works that discuss the cosmological model of the divinity of Ibn al'Arabi.

Writings of Muhȳì l-Dīn Ibn Al- 'Arabī,' Studia Islamica 115, no. 1 (September 2, 2020): 33-64, https://doi.org/10.1163/19585705-12341406. 


\section{IBN AL-'ARABI IN ISLAMIC MYSTICAL TRADITION}

The mystical tradition of Islam began with the zubud attitude of the rabid who criticized the glamorous life and hedonism of the Umayyad caliphate in the $1^{\text {st }}$ and $2^{\text {nd }}$ centuries $\mathrm{AH} / 7$ and 8 AD. The emergence of various studies on the moral sciences. In this century, 2 (two) distinctive features of Islamic mysticism stand out, regarding ethics and the strong element of philosophy, which later has made some people think that Islamic mysticism has come out of the Islamic element.

Until al-Gazali came after him in the 5 th $/ 11$ th century $\mathrm{AD}$, who reconciled the mystical Islam and the Shari'a which made Islamic mysticism respected again. In the subsequent developments of the 6th and 7th centuries $\mathrm{H} / 12$ and $13 \mathrm{AD}$, Islamic mysticism reappeared with strong philosophical elements, one of which was developed by Ibn al-'Arabi, which then in the hands of Ibn al-'Arabi there was a peak of brilliance in the field of mystical philosophy. and its influence continues to flow from time to time. ${ }^{2}$

It is no doubt that Ibn al-'Arabi is one of the pinnacles of brilliance in the field of mystical philosophy in his time and his influence keeps flowing from time to time. He was born in Andalus, Murcia Spain in 1165 AD. His full name is Muhammad Ibn 'Ali Ibn Muhammad Ibn al'Arabi al-Tha'i al-Hatimi. When he was eight years old, his family brought his move to Lisbon and later move to Seville. In Seville, he started to study and deepen his Islamic knowledge from many different branches to the Islamic scholars and the Sufis. ${ }^{3}$

While in Seville, in the further time, Ibn al'Arabi occupied a position as Secretary to the Governor of Seville, this is inseparable from his brilliance educational achievement. $\mathrm{He}$ later

2 Rifi Bachrun and Hasan Mud'is, Filsafat Tasawnf (Bandung: Pustaka Setia, 2010).

${ }^{3}$ Gregory A. Lipton, Retbinking Ibn 'Arabi, vol. 1 (Oxford University Press, 2018), https://doi.org/10.1093/oso/9780190684501.001.0001; Abdul Aziz Dahlan, "Pengajaran Tentang Tuhan Dan Alam: Paham Tauhid Ibn Arabi," Jurnal Ulumul Qur'an, no. 5 (1993); married a pious woman named Maryam. While in Seville, his wife is always there for him, including during his visitation to many areas in Spain and North Africa. ${ }^{4}$ During his visitation, he met numerous Sufi teachers. This has triggered him to keep pace with the Sufism world since he was twenty years old, in which he finally decided to go with Sufi and help him to become a great Sufi.

Ibn al-'Arabi isn't only a great Sufi but also a mystical philosopher. His mastery of knowledge is beyond the mystical realm. He masters the peripatetic philosophy as well that he is one of the teachers in that field. With a background of mastery of a wide variety of disciplines (between mystical and philosophy), Ibn al-'Arabi can formulate his mystical point of view by using philosophy language. In other words, his inward experiences had been philosophized and became satisfactory metaphysics. Thus, this is well known as wahdat al-wujud. ${ }^{5}$

\section{MYSTICAL APPROACH METHOD OF IBN AL-'ARABI}

Generally, the mystics had the same experience in the inward level, even though it is not in the same depth level. The inward experience of the mystics is an event that is beyond ordinary human's experience due to the object met in the inward realm is something different from the object known in the real world. As the effect, the role of language is experiencing traffic due to its inability to state the remarkable thing in the inward realm.

The inward experience of the mystics tends to be considered as contradictive or in opposition to the common appropriate thing or the fittingness of the general point of view. The most frequent thing that invites controversy from

Ahmet Kamil Cihan, "The Notion of Religion in the Fusus Al-Hikam of Ibn Arabi," AFKAR Journal of Aqidah and Islamic Thought 11, no. 1 (2010).

${ }^{4}$ Kautsar Azhari Noer, Ibn Al-'Arabi: Wabdat AlWujûd Dalam Perdebatan (Paramadina, 1995).

${ }^{5}$ Noer. 
the mystics is shatahat which was produced at the time of stay.

Overall, shatahat is produced at the peak of mystics' inward experience, that is in the phase of unification with God; hence, they are no longer in the ordinary consciousness, but they are at suprahuman consciousness, in which human consciousness is absorbed into the consciousness of God. The problem experienced by the mystics when their consciousness isn't at the level of human is an inability to formulate the deepest experience due to the limitation of tool used to reveal; hence, the expression produced by the mystical experience is meaningless and considered as a mislead for the common people. ${ }^{6}$

The main problem in formulating mystical experience is probably due to inappropriate balance work of common sense in understanding the experience resulted from the inward upgrade. Therefore, Ibn al-'Arabi tried to combine the mystical approach and philosophy which is aimed to enable the interpretation of inner language in revealing God, even though this is complicated as well as controversial.

The approach employed in understanding mystical experience (particularly in the context of unification with God) depends on the type of discipline. William Chittick revealed that Ibn al'Arabi divided two kinds of basic knowledge, namely, knowledge obtained through rational ability, as for the other one is obtained from spiritual practice which is well known as gnosis (ma'rifah). This second type of knowledge is also used to call disclosure (kasyf), or close to some

6 Media Zainul Bahri, "Ibn "Arabi and the Transcendental Unity of Religions," Al-Jami'ab: Journal of Islamic Studies 50, no. 2 (December 27, 2012): 461, https://doi.org/10.14421/ajis.2012.502.461-483; Farhad Amoorezaei, "Analyzing the Position of Mystical Intuition, Imagination and Reason in Mola Sadra and Ibn Arabi Theosophy," International Journal of Multicultural and Multireligious Understanding 7, no. 3 (April 22, 2020): 143, https://doi.org/10.18415/ijmmu.v7i3.1411.

${ }^{7}$ William C Chittick, The Sufi Path of Knowledge: Ibn Al-Arabi's Metaphysics of Imagination (SUNY Press, 2010); James Winston Morris, William C. Chittick, and Ibn Al'Arabi, 'The Sufi Path of Knowledge: Ibn Al-'Arabi's terms like dzauq, fath, bashirah, shubud, and mushahadah. $^{7}$

The approach introduced by Ibn al-'Arabi is not very distinct from the approach introduced by the previous mystics. Those approaches focus on the kashfi approach. The difference between Ibn al-'Arabi and the other mystics is the ability to use his philosophy basic to elaborate his mystical experience as to describe it as far as it is can be understood and processed by common sense.

The effort in describing a mystical approach is almost impossible without the help of active common sense. Hence, it is no wonder that Ibn al-'Arabi always trying to liven up the imagination in picturing mystical experience, particularly when it comes to God in a way that simultaneously directs to the transcendence and immanence of God. Even though the describing effort is conducted indistinctly, at least it can tell us about the existence of the divine which covers the Essence of God. ${ }^{8}$ The mystical approach implemented by Ibn al-'Arabi is nothing but the form of transferring "image" of divinity in an inward vision (witnessing) as a way to get close to God which does not merely rely on common sense, but far at the level of the infinite ocean divine.

Mehdi Ha'iri Yazdi revealed that the brilliance of Ibn al-'Arabi in transferring the inward experience into a mystical truth is inseparable from his expertise in using the Irfan method. This method is pioneered by himself. In this context, Ha'iri Yazdi considered Irfan as a language science of mystical awareness.' Irfan's

Metaphysics of Imagination," Journal of the American Oriental Society 111, no. 3 (July 1991): 601, https://doi.org/10.2307/604289.

8 Annemarie Schimmel, Deciphering the Signs of God: A Phenomenological Approach to Islam (State University of New York Press, 1994).

${ }^{9}$ Mehdi Ha'iri yazdi, The Principles of Epistemology in Islamic Philosophy: Knowledge by Presence, SUNY Series in Islam (State University of New York Press, 1992); Kautsar Azhari Noer, "Kebutuhan Untuk Mempromosikan Irfan Dalam Sufisme Perkotaan," Ushuluna: Jurnal Ilmu Ushuluddin 1, no. 1 (April 12, 2020): 72-93, https://doi.org/10.15408/ushuluna.v1i1.15153. 
approach can be differentiated by using the common intellectual science method. Chittick in Futuhat of Ibn al-'Arabi mentioned three classifications of science approach. Firstly, intellectual knowledge (Tlm al-Aql The Science of reason) is obtained through an investigative approach and it is demonstrative. ${ }^{10}$ This type of knowledge can be referred to empirical object or the object recognized by common sense.

Secondly, it is the knowledge about the awareness of inward situations (the science of states, abwal). This type of knowledge focuses more on the ability to feel, therefore, there is no way in communicating situations that are far beyond common sense but to feel them directly. In relation to this second type of knowledge, common sense is no longer compatible to be the reference in proving the truth of the "situations" in terms of inward witnessing. Simply, take the example of the sweet taste of the honey or the bitter taste of sandalwood. These tastes simply need to be tasted to get to know them. Overall, it has nothing to do with representing the existence of the sweet and bitter tastes as concrete material things. ${ }^{11}$

Thirdly, the knowledge about the mysterious matter (knowledge is the science of the mysteries, ilm al-asrar). This type of knowledge is transcendence intellectual in which its disclosure is depending on the divinity light or the light of pure spirit into human thought. This type of knowledge is only possessed by those who reach the highest maqam such as the Prophets or the holy people. ${ }^{12}$

The third type of knowledge ( $\mathrm{ilm}$ al-asrar) tends to get more priority in the approach of Ibn al-'Arabi in order to achieve knowledge about God through the inward version. Ha'iri Yazdi stated that transcendence intellectual knowledge ( $\mathrm{ilm}$ alasrar) is the reverse form of phenomenal

${ }^{10}$ Morris, Chittick, and Al-'Arabi, "The Sufi Path of Knowledge: Ibn Al-'Arabi's Metaphysics of Imagination"; Reynold Alleyne Nicholson, The Mystics of Islam, Library of Alexandria (Library of Alexandria, 2020).

11 Morris, Chittick, and Al-'Arabi, "The Sufi Path of Knowledge: Ibn Al-'Arabi’s Metaphysics of Imagination”; Nicholson, The Mystics of Islam. representation applied for physical objects sensed by human senses. Meanwhile, transcendence knowledge is the knowledge of a mysterious realm in which it is hard to be described at a certain level since common sense and language are not able to reach foreign inward realms to later be processed by the mind. ${ }^{13}$ In other words, the inward objects can be seen solely through inward vision without invoking common sense and language.

Nevertheless, language and common sense are inseparable in participating in the inward realm. However, Ibn al-'Arabi mentioned that the kasyfi approach is more prioritized. This is in line with the elaboration of Ha'iri Yazdi about the role of common sense concerning the mystical view of Ibn al-'Arabi as follow:

"Ibn al-"Arabi revealed that common sense has the capability to re-introspect and reformulate this kind of knowledge and bring it back into the phenomenon world. Once common sense has taken this step thoroughly, re-arrange and re-interpret the knowledge that is impossible to explain into the framework, the form of knowledge is phenomenal and representational ways; hence, the knowledge will turn into ordinary intellectual knowledge, just like the other knowledge which is conceptual and understandable, and therefore can be interpreted easily into daily utterances. In brief, Ibn al-'Arabi revealed that the capability of common sense can transmit the knowledge of mysterious realm into intellectual knowledge of phenomenon world." 14

The role of common sense is vital importance in bridging or in communicating mysterious experiences based on the point of view applied in the empirical reality. The use of common sense in this context is to seek any

${ }^{12}$ Ha'iri yazdi, The Principles of Epistemology in Islamic Philosophy: Knowledge by Presence.

${ }^{13}$ Ha'iri yazdi.

${ }^{14}$ Ha'iri yazdi. 
possibilities in interpreting experiences obtained from the mystical realm into statements by borrowing many known terminologies. The interpretation of mystical experience via common sense is aimed to create a balance of relational awareness between intellectual faculty and intuition sharpness to allow the trans existence of phenomenal knowledge through representation. ${ }^{15}$

The next sequence in the context of the mystical approach by Ibn al-'Arabi is related to means or instruments used to employed to obtain divinity knowledge. Generally, in the mystical tradition inward instrument is widely known. Nicholson stated that Sufi classified three types of the organ that can be called an inward communication tool, namely, heart (qalbu), spirit (rub), and the deepest soul (sirr), each organ has its function. "Heart (qalbu) to get to know God, spirit (rub) to love God, the deepest part of the soul (sirr) to think of God". ${ }^{16}$

Based on its function, the heart is of vital importance to reveal the divinity reality. In this term, the heart is not the physical thing (which consists of meat and blood), nevertheless, the heart has a mysterious connection to the physical heart of the human body. About the description of the heart, Nafis revealed that Ibn al-'Arabi assumed it as a shiny mirror which can be blurred, and therefore each heart needs to be cleaned or purified by doing worship. ${ }^{17}$

The parable of the heart is like a shiny mirror which has a similarity with the idea of alGhazali who mentioned that the heart is like a clear mirror in which its clarity can discover the hidden secrets. ${ }^{18}$ Through this clarity of the heart; hence, the guidance in the form of divine inspiration is always with its worshipers. In this context,

15 Nurcholish Madjid, "Beberapa Renungan Tentang Kehidupan Keagamaan Untuk Generasi Mendatang," Jurnal Ulumul Qur'an, no. 1 (1993).

${ }^{16}$ Nicholson, The Mystics of Islam, 65.

17 Madjid, "Beberapa Renungan Tentang Kehidupan Keagamaan Untuk Generasi Mendatang"; Jalaluddin Rakhmat, Rekonstruksi Dan Renungan Religius Islam, ed. Muhammad Wahyuni Nafis (jakarta: Paramadina, 1996).
Schimmel revealed Ibn al-'Arabi asserted that in writing his famous masterpiece, Futubat alMakkiyyah, there is no letter written but under the guidance of divine of God. ${ }^{19}$

In a higher inward level, the heart accepts more than just God divinity, but through the level of its clarity can witness tajalli of God (God exists in inward version), in which the curtain that obstructs the inward "sight" there is no any reality but the reality of God. Nurcholish Madjid argued that with the above problem, Ibn al-'Arabi has revealed that when the reality of the mysterious realm is uncovered, everything is clear, it is no difference between close and open eye, the witnessing is no more depending on the physical eye ${ }^{20}$ this is called kashf.

From the description above, the kashf method is the method used by Ibn al-'Arabi in the mystical approach. With the kashf method, Ibn al'Arabi transfers the image of divinity in his inner witnessing closer to God, by relying on his thoughts and inner eyes.

\section{DIVINITY THOUGHT OF IBN AL-'ARABI}

As with other Sufis who have limited thoughts about divinity, Ibn al-'Arabi also developed it - which in the time of Ibn al-'Arabi, the limit of thinking about divinity was at its peak. In a sense, these thoughts influence mysticism in Islam as in previous traditions. As for among the divine thoughts of Ibn al-'Arabi, namely:

\section{Existence}

God in the mystical philosophy of Ibn al'Arabi is a single Substance that embodies other than its substance. God Substance is the one and the only thing called as exist. God is inseparable

18 Abu Hamid Muhammad Al-Ghazali, Mishkeat AlAnwar, Asiatic Society Monographs, 2014.

19 Binyamin Abrahamov, Ibn Al-Arabi's Fusus AlHikam: An Annotated Translation of "The Bezels of Wisdom," Routledge Sufi Series (Routledge, 2015).

20 Madjid, "Beberapa Renungan Tentang Kehidupan Keagamaan Untuk Generasi Mendatang"; Schimmel, Deciphering the Signs of God: A Phenomenological Approach to Islam. 
and independent. ${ }^{21}$ Existence is also known as an absolute reality, which in the other understanding God is considered as a consciousness experienced by God itself in finding itself. More assertively, the term of existence according to Ibn al-'Arabi is only aimed at God, and anything other than God is not eligible in applying that term (masiwallab). However, it is undeniable that Ibn al-'Arabi is using the term of existence for something other than God, but the context is in the metaphoric (majazl) definition. It is also important to remember that the use of existence term for something other than God is not to separate its possessiveness from the actual existence, God. In other words, it can be said that the existence or the shape attached to things is borrowed from God (accidents). ${ }^{22}$

Furthermore, existence can be differentiated from adam (non-existence), however, adam does not apply to God since God is the real existence; hence, existence and adam are for something other than God because God is relative. $^{23}$

\section{Substance}

In general, the term substance is used in many different contexts, such as to name a person or thing, or it can also be as the essence or substance of a thing. Concerning the thought of divinity, the term substance is used to call "the self" of God, as for existence is the emphasis on "the presence" of God substance.

As mentioned previously, the existence of God is independent. God is "present" due to and with its substance. Meanwhile, something other than God (the universe) is present due to God. As an independent substance, God is free to determine itself, and its self-determination gave rise to differentiation in its substance. There are

21 Noer, Ibn Al-'Arabî: Wabdat Al-Wujûd Dalam Perdebatan, 42-43; "Ibn Al-'Arabi, Fushush Al-Hikam," n.d., 6, 77.

22 Noer, Ibn Al-'Arabî: Wabdat Al-Wujûd Dalam Perdebatan.

${ }^{23}$ M. Saeed Sheikh, A Dictionary of Muslim Philosophy (Institute of Islamic Culture, 1970), 71. many other stages of God in determining and managing itself, and these two acts affect "the presence" of the other. Firstly, God is the substance that manages itself, and this stage is called Abadiyyah (absolute unity). Secondly, God determines and unveils itself, thus this has cause inward differentiation of God's substance. As the effect, ideas about something (the world) then arise in the thought of God with all of its ideal form (al-ayan al-tsabitab), which is the formal images or the blueprint of everything in the world which is yet to be created. These ideal images are inseparable from God, the angel is bent down to God. Thus, this stage is called wabdab (one and only). Thirdly, God's substance determines the existentialism toward objects related to the ideal image in the thought of God (al-a'yan al-tsabitah) by using the knowledge possessed by God itself. This stage is called wabidiyyah. ${ }^{24}$

There are three more stages about determination offered in the context of divinity thought of Ibn al-'Arabi, namely, ta'ayyun rubi, or determination of substance toward spirit, ta'ayyun mitsali is the determination of substance toward symbolic form. The next one is ta'ayyun jasadi, it is the determination of substance toward the body. ${ }^{25}$ The determination form of substance toward God itself, will give rise to something else. As mentioned in the above explanation, it is the willingness of the one and only God to show itself through something else (universe) or known as tajalli.

\section{Immanence and Transcendence}

In discussing immanence and transcendence, God is inseparable by emphasizing only one aspect which becomes the tendency, whether it is individual or group. It has to be admitted that, God's divinity aspects (immanent

${ }^{24}$ Muhyiddin Ibn Al Arabi, Futuhat Al-Makkiyah, Jilid II (Darul Futuhat, n.d.), 433; Noer, Ibn Al-'Arabî: Wabdat Al-Wujûd Dalam Perdebatan.

25 Noer, Ibn Al-'Arabî: Wabdat Al-Wujûd Dalam Perdebatan. 
and transcendent) are two reverse poles (coincidentia oppositorum). In the side of God, it is understood as zhabir or visible, but also as bathin, the invisible. God as Zhahir has similarity (tashbih) with things other than itself, but as Bathin, God shows dissimilarity, incomparable (tanzi $i$ ) ${ }^{26}$

Chittick mentioned that those two different terms are related with the appearance of God as far as it is can be absorbed, such as: in the context of tasybih, al-zhabir, God as the Almighty Visible means that God shows itself via the manifestation of its names, which are the quality attached to its existence. Meanwhile, in the context of tanzih, the definition of al-bathin as the Almighty Invisible reflects that God is unreachable, beyond perception and understanding. the emphasis of tanzib in the thought of Ibn al-'Arabi is mentioned in Futuhat as quoted by Nurcholish Majid, as follow: $:^{27}$

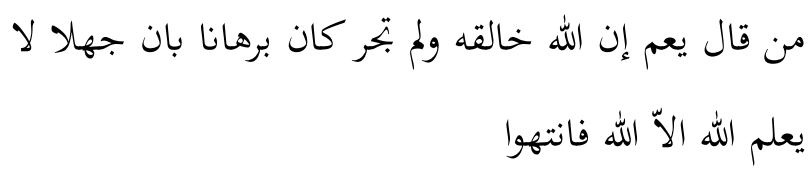

For those who claimed that he knows Allah is befriended with itself, and he stays with that claim, it shows that this person knows nothing. No one knows about Allah, but Allah itself, so be aware.

The above definition shows that the transcendence of God emphasizes the occurrence of unlimited distinct between God and its creation. This implies a thankful relationship between God and its creation. Nevertheless, the concept of immanence and transcendence are inseparable in the thought of Ibn al-'Arabi, even though they are contradictory to one another. This kind of contradiction is understandable as long as it is used to elaborate God based on its context.

\footnotetext{
${ }^{26}$ Chittick, The Sufi Path of Knowledge: Ibn Al-Arabi's Metaphysics of Imagination, 80.

27 "Ibn Al-'Arabi, Fushush Al-Hikam," 81; Madjid, "Beberapa Renungan Tentang Kehidupan Keagamaan Untuk Generasi Mendatang"; Morris, Chittick, and Al'Arabi, "The Sufi Path of Knowledge: Ibn Al-'Arabi's Metaphysics of Imagination.”
}

Abdul Haq Ansari revealed that the thought of Ibn al-'Arabi about immanence is aimed to explain that God is very close as long as it is related with the world or in the microscopic size it relates with the human being. Next, the transcendence aspect is aimed to explain that God is transcendence as long as it is different from the world. The difference between God and the other thing is implied in its characteristics, namely, unlimited, the Almighty Creator, and the other characteristics which is part of transcendence. ${ }^{28}$

\section{Tajalli of God}

The concept of tajalli is assumed to have a central position in the perception of Ibn al-'Arabi, particularly in building the doctrine of wabdat alwujud, even in a broader way, the whole philosophies of Ibn al-'Arabi are inseparable from the theory of tajalli. The term tajalli has many definitions, Chittick mentioned that sometimes it is defined as self-disclosure or self-manifestation. ${ }^{29}$ Tajalli or disclosure is a form of God immanence in which God can be approached by its servants through this, also God itself can stay closer to its servant.

Tajalli of God in the thought of Ibn al'Arabi is directed into two, namely, the universe and human being in the tajalli of God. God as the Almighty only shows itself in diversity or the other term known as wabdat and katsrah. Knowing tajalli with the universe can be described as a form of the longing of God in witnessing its beauty though (mirror) universe; hence, it is understandable that the presence of the universe is due to the mazhar of God (the place for God to expose itself). The other interpretation of God disclosure via the creation of the universe is not solely to allow God to see its image, but also to reveal itself to all of its creations, particularly to the human being. ${ }^{30}$ Sachiko Murata Perdebatan, 59.

28 Noer, Ibn Al-'Arabî: Wabdat Al-Wujûd Dalam

${ }^{29}$ Ibn Al Arabi, Futubat Al-Makkiyah, Jilid II, 488; Morris, Chittick, and Al-'Arabi, "The Sufi Path of Knowledge: Ibn Al-'Arabi's Metaphysics of Imagination," 91.

${ }^{30}$ Noer, Ibn Al-'Arabî: Wabdat Al-Wujûd Dalam Perdebatan, 43. 
stated that Ibn al-'Arabi completed his argumentation by quoting the hadith of the Prophet as follow: ${ }^{31}$

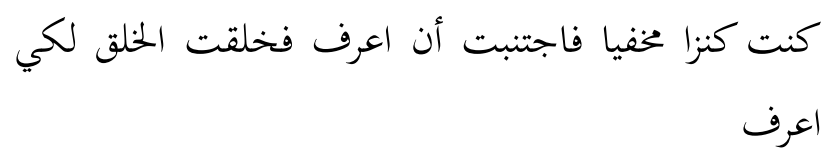

"I am the invisible substance and so I would like to be known; hence, I then create the creature so that I can be unveiled."

The other explanation about tajalli is discussed by Schimmel. Schimmel argued that in this case, Ibn al-'Arabi developed a myth of God's names which reflects longing and loneliness in its solitude. God's names are "non-existence", that is yet to be actualized in the "Divine depth." In the actuality level, these names are exploded out and followed by an action, that is the blast of the divine. After God's names present themselves in the universe, then all creatures are experiencing contact with God's names to achieve their existence. Furthermore, it is stated that the presence of the universe or all creatures are the result of the manifestation of God's love toward itself, in the other word, it can be said that tajalli can be defined as the manifestation of al-Rahman blast which distributes the fragrance of yearning to all parts of God's creatures. ${ }^{32}$

The whole manifestation of God in all of its creatures is the "mirror" that reflects "God's image", and amongst all of its creatures, a human being is the only one who can be the most perfect "mirror" in receiving the reflection of "God's image", since human being contains "shurab" (shape) of divinity and automatically human being is containing God's characteristics. Tajalli of God in the human being is started from the figure of Adam. Adam radiates and reflects the whole of God's names. As for the peak of human being

${ }^{31}$ Sachiko Murata, The Tao of Islam: A Sourcebook on Gender Relationships in Islamic Thought (SUNY Press, 1992), 33.

32 Sachiko Murata and William C Chittick, The Vision of Islam (Suluh Press, 2005).

33 Majid Fakhry, A History of Islamic Philosophy (Columbia University Press, 2004). perfection is contained in Muhammad Shallaullahu 'alaihi wa sallam or known as al-mir'ah alMubammadiyyah (the reflection of Muhammad). Therefore, Muhammad is the picture of a perfect human being, which in himself containing the fullest and the most perfect manifestation of God. ${ }^{33}$

In general, the human being is the compilation of the whole image of all creatures in a miniature form and all at once also determine the perfection of divinity characteristics. ${ }^{34}$ The characteristics of God attached to the human being is the potential form to understand tajalli of God in himself. The blast of the divine spirit in human beings allows the love energy to be born as the reaction form toward longing of God to its creatures. Thus, this is presenting its actual form between al-haq and al-khalaq to allow mutual longing which is directed to unification, like the unity of sun and light. In this level of understanding, Ibn al-'Arabi bravely stated that alkhalaq is al-haq, but at the same time he stated that al-khalaq is different from al-haq, since al-khalaq is assumed as a colorful light, as for the source of the light (al-baq) itself has only one color. ${ }^{35}$

The concept of unification in the thought of Ibn al-'Arabi, particularly wabdat al-wijud seems to be understood as the peak of two forms of yearning who are willing to be reunited. The human being with the potential to has longing and o be united with the source of longing always willing to "witness" the face of God in the unveiling. To reach this level, a human needs to begin with understanding himself to be able to capture the manifestation of God's characteristics in his conscious mirror. In relation to this, Ibn al'Arabi revealed his argumentation as follow'

${ }^{34}$ Huston Smith, The Religions of Man (Ishi Press International, 2012), 46.

35 Abrahamov, Ibn Al-Arabi's Fusus Al-Hikam: An Annotated Translation of "The Bezels of Wisdom," 215.

36 Abrahamov, Ibn Al-Arabi's Fusus Al-Hikam: An Annotated Translation of "The Bezels of Wisdom"; Noer, Ibn Al'Arabî: Wabdat Al-Wujùd Dalam Perdebatan, 43. 


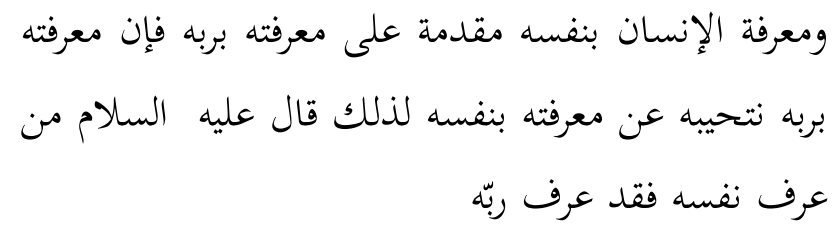

"Human recognition of himself is his muqaddimah or ma'rifat toward his God, in which his ma'rifat toward his God is natijah (the result of logical conclusion) or his ma'rifat toward himself, as told by the Prophet, he who knows himself has known his God."

Referring to the above explanation, it is clear that to reach God, it is a must went through the phase of self-recognition since a human can't reach the highest goal without seeing the display of God's characteristics in the mirror of themselves. Self-recognition can also be one of the ways to release the cover one by one from fantasy so that the spirit can accept the reflection and can "discern" the divinity reality. In the other words, it can be stated that recognition can also be defined as an effort toward isti'dad (readiness) in accepting each unlimited tajalli of God.

Overall, the main part of tajalli is the appearance of God as a diverse disclosure. This diversity is due to the reflection of God's names. God then choose humans as the most perfect majla and mutajalla. The following is a schematic of Ibn al-'Arabi's divine cosmology.

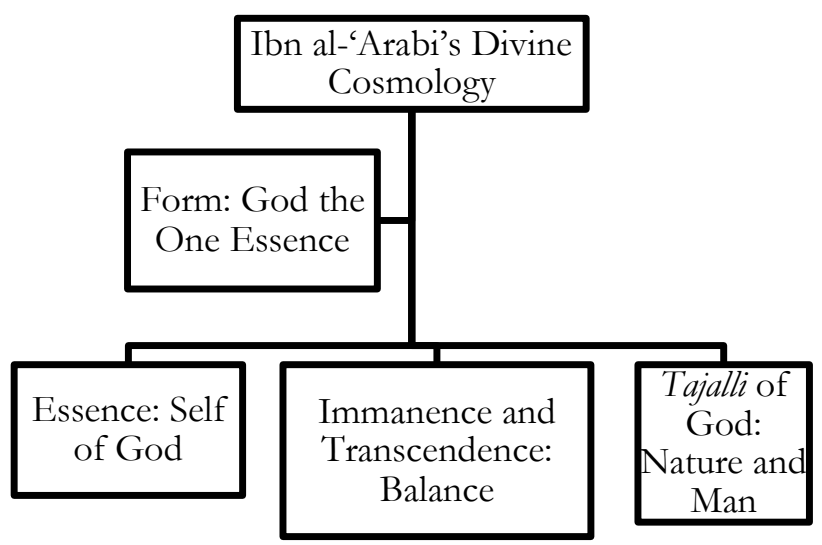

${ }^{37}$ Lorens Bagus, Kamus Filsafat (Gramedia Pustaka Utama, 2000), 70.

38 Haidar Bagir, Buku Saku Tasawuf (Bandung: Mizan, 2006); Muhammad Basyrul Muvid, TIPOLOGI
The divinity thought with philosophical motive as well as mystical of Ibn al-'Arabi's inseparable from the previous sequence of thought. Generally, mystical philosophy thought in Islam has a very close relationship with the Greek tradition of thought. Even, the thought of Ibn al'Arabi is inseparable from the influence of Neoplatonism. It is widely known that the philosophy of Neoplatonism always links God to the principle of unity which emphasizes the aspects of immanence and transcendence, unification and diversification, and on the other side, the philosophy of Neoplatonism also support elements of mystical religion. ${ }^{37}$ Haidar Bagir argued that the concept of al-ayan al-tsabitab is the influence of Greek thought which is Platonism type. $^{38}$

Besides, Ibn al-'Arabi is inseparable from Andalus intellectual tradition which is very rich with its numerous studies of philosophy and mysticism. The names like Ibn Bajjah and Ibn Thufayl are mystics philosophers which precedes the great name of Ibn al-'Arabi in which one of these two has Platonism thinking model in building his mystical thought. For example, once Ibn Thufayl focuses on spiritual discipline, he believed that the highest truth is no more achieved through deduction and induction processed, but they can be obtained directly through intuitive ability. One of the Ibn Thufayl's point of view which is mystical is about the existence of a single substance which resulted in numerous things, this can be assumed as the ray of the sun that touches the mirror surface and eventually this mirror reflects the colorful ray, however, the diversity of the color will be disappeared when the main focus is the source of the light itself in which there is one light. ${ }^{39}$

Ibn Thufayl thinking model which is mystical at least provides influence to the generation after; hence, it is no surprise that Ibn al-

ALIRAN-ALIRAN TASAWUF (Yogyakarta: Bildung, 2019).

39 M. Hadi Masruri, Ibn Thufa'il; Jalan Penceraban Mencari Tuhan (Lkis Pelangi Aksara, 2005), 185, 187. 
'Arabi has the same point of view in constructing mystical experience into a mystical philosophy thought.

The other figure with a similar approach model in the divinity thought is Farid al-Din Attar. He metaphorically elaborated his thought of divinity through the figure of si-Murgh (thirty birds) which yearn for the meeting with the king of the bird (si-Murgh). In his work manthiq al-thayr, it is told that at the peak of the search, the Salik which is simurgh (thirty birds) experiencing disclosure. All and all, right at that moment the thirty birds are finally able to see the face of si-Murgh (the king of bird), in huge astonishment, the thirty birds find it hard to convince themselves whether they are still simurgh or they are becoming si-Murgh. They found that the thing they witness is the reflection of themselves. At that very moment, si-Murgh revealed its secret that it unveils itself in the image of the thirty birds, in case the number of the birds are more than thirty, then si-Murgh will go with that number as well. ${ }^{40}$

The image of the longing of si-murgh is nothing but the personification of humans who yearns for the beauty of "the face" of his God. It is no wonder that Ibn al-'Arabi lavishes his longing in his du'a which is "oh God, sink me in your unlimited only realm". ${ }^{41}$

Ibn al-'Arabi point of view about the mystical experience or inward experience in "witnessing" God is challenged strongly by Iqbal even though Iqbal is not arguing for all of Ibn al'Arabi's inward experiences. The critique by Iqbal is on a conceptual level. Iqbal argued that $W$ abdah and Katsrah do not even exist, the only thing that matters is tawhid against shirk. ${ }^{42}$

40 "The Conference of the Birds" (World Wisdom, Inc, 2012), 237-39; Alexander Bird, Philosophy Of Science (Routledge, 2006), https://doi.org/10.4324/9780203133972.

${ }^{41}$ Musa Asy'arie, Islam, Kebebasan Dan Perubaban Sosial: Sebuab Bunga Rampai Filsafat, ed. Musa Asy'arie (Jakarta: Sinar Harapan, 1986), 34.

42 Sevcan Ozturk, Becoming a Genuine Muslim (Routledge, 2018), https://doi.org/10.4324/9781351169288; A.J. Arberry, Sufism

(Routledge,
Iqbal's critical point of view can be understood as the strong influence of previous Sufi, Ahmad Sirhindi which also rejects the concept of wahdat al-wujud. However, there is one spotlight to be criticized that is when Iqbal critics Ibn al-'Arabi arguably, he never talks about Rumi, whereas Nasr revealed that Rumi's work, Matsnawi is considered as a Futuhat in Persian language and Rumi himself is a lot under the influence of Ibn al'Arabi's thought via Shadr al-Din Qunyawi.

The rejection toward divinity thought of Ibn al-'Arabi as discussed previously is mainly on a conceptual level since some people who disagree on his point of view, consider the language term employ to interpret inward experience such as wabdah and katsrah are too risky. Ibn Taymiyyah, for example, as quoted by Muh. Ilham Usman, who criticized Wahdat al-Wujud Ibn al-'Arabi, said that this understanding said that Allah did not create anything. If what exists in this universe is His form. So, it is impossible for Him to create His own Essence. Because anyone's mind believes that something cannot create itself. ${ }^{43}$ Nevertheless, out of many controversies, the mystical thought of Ibn al-'Arabi is a result of creation that is aimed to combine mystical religious experience with the ability of common sense. Moreover, common sense may help to articulate the inward experience, even though it is complicated.

\section{CONCLUSION}

The thought of Ibn al-'Arabi has already been disseminated broadly across regional or continental borders. His tracks of mind are in each generation, even until today his thought is still appreciated widely in Western, that is in America

https://doi.org/10.4324/9780203706848; Mark Sedgwick, "Ibn 'Arabi and the Contemporary West: Beshara and the Ibn "Arabi Society," Islam and Christian-Muslim Relations 25, no. 3 (July 3, 2014): 389-90, https://doi.org/10.1080/09596410.2014.880628.

${ }^{43}$ Muh Ilham Usman, "Meneroka Pemikiran Ibn Taymiyah," Rausyan Fiker: Jurnal Studi Ilmu Ushuluddin Dan Filsafat 16, no. 1 (July 1, 2020): 29-60, https://doi.org/10.24239/rsy.v16i1.533. 
and Europe, so it resulted in the coalescence of Ibn al-'Arabi Society. It is an association aimed to conduct seminary research and publication of history and thought of Ibn al-'Arabi, and his influence in mystical philosophy. The expansion of the influence of Ibn al-'Arabi in this recent time is due to degradation and dehydration of spiritual in the modern world. The human being who has uprooted from his roots wants to rediscover the consciousness spirit which is the radiance of divinity circle center.

\section{BIBLIOGRAPHY}

Abrahamov, Binyamin. Ibn Al-Arabi's Fusus AlHikam: An Annotated Translation of "The Bezels of Wisdom." Routledge Sufi Series. Routledge, 2015.

Al-Ghazali, Abu Hamid Muhammad. Mishkeat AlAnwar. Asiatic Society Monographs, 2014.

Amoorezaei, Farhad. "Analyzing the Position of Mystical Intuition, Imagination and Reason in Mola Sadra and Ibn Arabi Theosophy." International Journal of Multicultural and Multireligious Understanding 7, no. 3 (April 22, 2020):

143. https://doi.org/10.18415/ijmmu.v7i3.1411.

Arberry, A.J. Sufism. Routledge, 2013. https://doi.org/10.4324/9780203706848.

Asy'arie, Musa. Islam, Kebebasan Dan Perubahan Sosial : Sebuah Bunga Rampai Filsafat. Edited by Musa Asy'arie. Jakarta: Sinar Harapan, 1986.

Bachrun, Rifi, and Hasan Mud'is. Filsafat Tasawuf. Bandung: Pustaka Setia, 2010.

Bagir, Haidar. Buku Saku Tasawnf. Bandung: Mizan, 2006.

Bagus, Lorens. Kamus Filsafat. Gramedia Pustaka Utama, 2000.

Bahri, Media Zainul. "Ibn "Arabi and the Transcendental Unity of Religions." AlJami'ab: Journal of Islamic Studies 50, no. 2 (December 27, 2012): 461. https://doi.org/10.14421/ajis.2012.502.461483.

Basyrul Muvid, Muhammad. TIPOLOGI ALIRAN-ALIRAN TASAWUF. Yogyakarta: Bildung, 2019.

Bird, Alexander. Philosophy Of Science. Routledge, 2006. https://doi.org/10.4324/9780203133972.

Chittick, William C. The Sufi Path of Knowledge: Ibn Al-Arabi's Metaphysics of Imagination. SUNY Press, 2010.

Cihan, Ahmet Kamil. "The Notion of Religion in the Fusus Al-Hikam of Ibn Arabi." AFKAR Journal of Aqidah and Islamic Thought 11, no. 1 (2010).

Dahlan, Abdul Aziz. "Pengajaran Tentang Tuhan Dan Alam: Paham Tauhid Ibn Arabi." Jurnal Ulumul Qur'an, no. 5 (1993).

Ebstein, Michael. "Classifications of Knowledge in Classical Islamic Mysticism: From Eastern Sufi Sources to the Writings of Muh yī l-Dīn Ibn Al- Arabī." Studia Islamica 115, no. 1 (September 2, 2020): 33-64. https://doi.org/10.1163/1958570512341406.

Fakhry, Majid. A History of Islamic Philosophy. Columbia University Press, 2004.

Ha'iri yazdi, Mehdi. The Principles of Epistemology in Islamic Philosophy: Knowledge by Presence. SUNY Series in Islam. State University of New York Press, 1992.

"Ibn Al-'Arabi, Fushush Al-Hikam," n.d.

Ibn Al Arabi, Muhyiddin. Futubat Al-Makkiyah, Jilid II. Darul Futuhat, n.d.

Lipton, Gregory A. Retbinking Ibn 'Arabi. Vol. 1. Oxford University Press, 2018. https://doi.org/10.1093/oso/97801906845 01.001.0001.

Madjid, Nurcholish. "Beberapa Renungan Tentang Kehidupan Keagamaan Untuk Generasi Mendatang." Jurnal Ulumul Qur'an, no. 1 (1993).

Masruri, M. Hadi. Ibn Thufa'il ; Jalan Penceraban Mencari Tuban. Lkis Pelangi Aksara, 2005.

Morris, James Winston, William C. Chittick, and Ibn Al-'Arabi. “The Sufi Path of Knowledge: Ibn Al-'Arabi's Metaphysics of Imagination." Journal of the American Oriental Society 111, no. 3 (July 1991): 601. https://doi.org/10.2307/604289.

Murata, Sachiko. The Tao of Islam: A Sourcebook on Gender Relationships in Islamic Thought. SUNY Press, 1992.

Murata, Sachiko, and William C Chittick. The Vision of Islam. Suluh Press, 2005.

Nicholson, Reynold Alleyne. The Mystics of Islam. Library of Alexandria. Library of Alexandria, 2020. 
Noer, Kautsar Azhari. Ibn Al-'Arabî: Wabdat AlWujûd Dalam Perdebatan. Paramadina, 1995.

. "Kebutuhan Untuk Mempromosikan Irfan Dalam Sufisme Perkotaan." Usbuluna: Jurnal Ilmu Ushuluddin 1, no. 1 (April 12, 2020):

https://doi.org/10.15408/ushuluna.v1i1.15

153.

Ogunnaike, Oludamini. "Inception and Ibn 'Arabi." Journal of Religion \& Film 17, no. 2 (2013): 1-50. http://digitalcommons.unomaha.edu/jrf/vo $117 /$ iss $2 / 10$.

Ozturk, Sevcan. Becoming a Genuine Muslim. Routledge, 2018. https://doi.org/10.4324/9781351169288.

Rakhmat, Jalaluddin. Rekonstruksi Dan Renungan Religius Islam. Edited by Muhammad Wahyuni Nafis. jakarta: Paramadina, 1996.

Schimmel, Annemarie. Deciphering the Signs of God: A Phenomenological Approach to Islam. State University of New York Press, 1994.

Sedgwick, Mark. "Ibn 'Arabi and the Contemporary West: Beshara and the Ibn "Arabi Society." Islam and Christian-Muslim Relations 25, no. 3 (July 3, 2014): 389-90. https://doi.org/10.1080/09596410.2014.88 0628.

Sheikh, M. Saeed. A Dictionary of Muslim Philosophy. Institute of Islamic Culture, 1970.

Smith, Huston. The Religions of Man. Ishi Press International, 2012.

"The Conference of the Birds." World Wisdom, Inc, 2012.

Usman, Muh Ilham. "Meneroka Pemikiran Ibn Taymiyah." Rausyan Fikr: Jurnal Studi Ilmu Ushuluddin Dan Filsafat 16, no. 1 (July 1, 2020): 29-60.

https://doi.org/10.24239/rsy.v16i1.533. 